Hallsworth, A.G. and Coca-Stefaniak, J.A. (2018), "National high street retail and town centre policy at a cross roads in England and Wales", Cities, ISSN 0264-2751, https://doi.org/10.1016/j.cities.2018.03.002.

\title{
National high street retail and town centre policy at a cross roads in England and Wales
}

\author{
Alan G. Hallsworth ${ }^{\mathrm{a}}$ and J. Andres Coca-Stefaniak ${ }^{\mathrm{b}, *}$ \\ ${ }^{a}$ University of Portsmouth, Marketing and Sales Department, Portsmouth Business \\ School, Richmond Building Portsmouth PO1 3DE, United Kingdom. Tel. +44 (0)20 \\ 393232230. \\ ${ }^{\mathrm{b}}$ University of Greenwich, Marketing, Events and Tourism Department, Business \\ School, Old Royal Naval College, Park Row, London SE10 9LS, United Kingdom. \\ Tel. +44 (0)2083318309.
}

\section{Highlights}

- Institutional Theory shows factors beyond town planning are growing in importance and relevance to the viability of town centres: notably Competition Law.

- There appears to be a growing power shift from local authorities (city councils) to large retail companies and from superstores to discount retailers.

- The suitability of established retail formats needs to be questioned more effectively with regards to the current needs of town centres and their key local stakeholders, including residents. ${ }^{*}$ Corresponding author. Email addresses: alan.hallsworth@port.ac.uk (A. G. Hallsworth) and a.coca-
stefaniak@gre.ac.uk (J.A. Coca-Stefaniak). 


\begin{abstract}
For eighty years, UK government policy related to urban sprawl, town centres and high streets in England and Wales has been dominated by planning/land-use control. In the post-war period, retail developments have often been discussed in the literature on planning for places - but the wide range of pressures for retail change are rarely brought together. This review of policy discusses many of these pressures: many of which fall beyond the urban planning remit. For example, although retail planning regulations have been influenced by Central Place Theory, this theoretical framework offers no insight on those private sector businesses that interface with urban planning. Worse, few (if any) professional town planners study retailing before formulating plans. Furthermore, the willingness of successive governments to exert meaningful influence through planning rules has ebbed and flowed, leaving town centres at a potential crossroads. This study addresses the vital missing link to business operations - and the rising pressures upon them - using Institutional Theory. Building on the findings of this analysis as well as earlier studies from other parts of the world, this article outlines implications for the management of town and city centres in England and Wales.
\end{abstract}

\title{
Keywords
}

High streets; town centres; retail; policy; institutional theory.

\section{Introduction}

Is planning the dominant controlling influence on the built environment for retailing? Curiously, very few studies have addressed this question. Yet, in 2002, and in a short but powerful article, prominent Dutch planner David Evers saw Dutch "planning ideology... pitted against...free market competition" with the latter apparently having already "gained the upper hand" (Evers, 2002; p. 109). This reinforces the need for a country-centred approach to the analysis of urban planning policy as wider - and arguably more abstract - analyses can lack depth in their insights (see Holland, 2015). 
The drive for free market competition originated in the USA where planning controls are few (but see Beaumont, 2004). How do matters play out in other countries that do have planning rules? To assess this requires us to range widely in search of influences - including ones not often considered: yet urban landscapes have always been reflective of power (Zukin, 1993). The City of London/Canary Wharf axis is a clear spatial expression of the financial power that, post-sub-prime, has largely obliterated prior manifestations of London as a great harbour city. Note, too, that the financial climate has led to increasing income inequality with this, too, evident in the urban landscape. The link is that investors, eschewing poor investment returns, have turned to asset acquisition. This now expresses itself in an urban skyline of speculativelybuilt residential blocks. So, the urban landscape reflects sea-changes in economic fortunes. Retailing has itself imposed physical changes too, with the building of landmark department stores such as Harrods, Selfridges or, in France, Au Printemps. However, retail trade in England and Wales has itself long been buffeted by winds of financial and associated social change. This despite the economic and social significance of its turnover of $£ 350$ billion per annum and around 2.8 million employees.

In recent history, changing economic fortunes have often led to changing urban forms in retailing. For example, until the booming mid-1960s in England and Wales, there was, effectively, no out-of-town retailing at all. Since that time (Schiller, 1986), retailing has flowed out-of-town in a series of waves - driven by powerful retailers and developers. After a decade of post-sub-prime economic underperformance and social change it is time to reconsider whether or not this trend will, or can, can continue. Similarly, it is also worth considering how the driving forces of change have varied through time. For instance, when referring to 'recent changes in economic fortune' major changes at the highest level such as sub-prime or Brexit have to be taken into account in terms of their influence on current and further developments spatially and locally. As noted, it is 'The Planning System' which is expected to mediate urban spatial outcomes in England and Wales - in a not dissimilar fashion to other countries (Fernandes and Chamusca, 2014; Rao and Summers, 2016). A complex mix of history, plus, for example, the rise of the internet or the growing influence of China, sets the very widest background. In addition to this, there are the differences between national, supra-national or regional structures and regulatory 
regimes. Planning is a middle-order influence that may, literally, set in stone (or 'tin shed') structures that may not survive future vagaries of fortune or which now have to forge a changed identity in a rapidly changing world. In using the term middle-order, the intention is to separate planning from both global influences such as the internet which retailers can use but not control - and local particularities such as catchment area and spending power (for more detail see Hallsworth, 1997). Planning itself can be approached from several perspectives: Jackson (2006) contrasted studies by 'retail geographers' (e.g. Lowe (2000) with the long-term investment growth approach by land use economists. The latter demonstrates the enduring financial importance of property investment. Jackson reminds us that in Britain, land ownership and speculation are a store - and a source - of both wealth and status. This study adopts a holistic approach to retail by considering both in and out of town retail. Reeves (2015), studied 56 retail planning appeals, noting: “... high number of unsuccessful appeals...for reasons unrelated to retail policy" (Reeves, 2015; p2 authors' emphasis). Given the existence of other criteria influencing store-related outcomes an Institutional Theory approach is adopted in this policy analysis, which concentrates on England and Wales since the position in Scotland can differ.

\section{Institutional Theory}

From a retail research perspective, the most prominent papers on Institutional Theory came from Arnold and Sternquist (see Handelman and Arnold, 1999). This approach (Huang and Sternquist, 2007; p.614) stresses “...political, cognitive and sociological elements such as laws, rules, norms, cultural beliefs and habits...”. Transparently, a 'planning system' is a key element of the Institutional environment that businesses must understand - especially when venturing abroad (note Carrefour's failure in the USA long ago). A more recent example is from Korea foreign entrants WalMart and Carrefour soon failed (Kim and Hallsworth, 2013). Similarly, Bianchi (2008) exemplified Institutional issues with her study of Home Depot in Chile. Yet, in the USA, where planning does not loom large, early evidence emerged that the issues faced by retailers were perhaps altogether more complex than first thought, with other regulatory forces were at play. While its rivals saw retailing as "ossified... constrained to exploit only...locational opportunities and transaction cost savings...WalMart 
proved them wrong" (Hallsworth and Taylor, 1996; p.2134). What WalMart exploited was not planning but the neo-liberal post-Reagan economic climate that saw a huge decline in anti-trust prosecutions. WalMart used its financial power to move into Canada via the purchase of Woolco stores and many of its US rivals were transformed by financial leveraging. Against this backdrop of evidence in the UK and internationally, this study seeks to identify regulatory sea changes that may benefit some domestic (and possibly foreign) retailers more than others.

\section{The influence of planning}

In this section, as in subsequent ones, the urban planning literature is analysed as a source of evidence to elicit an answer to the above question, though a single overall literature review could not encompass all the wider trends examined here; some of which are rarely linked together in earlier studies. Fundamentally, it could be argued that all these trends are in some way or another, rooted in places. Furthermore, the policy changes that benefited WalMart in the USA do not translate precisely to England and Wales where control of land use has long been an important part of regulatory norms for retailers and others. The changing fortunes for retail formats have often been linked to a perceived conservatism within planning regulation. Note that Planning exists to control development not prevent it - but how much residual influence does it really have when compared to other influences? In the UK, 1930's utopianism was embraced in the immediate post-war period with a collective belief in orderly planning manifest in the 1947 Town and Country Planning Act. Note that the retail sector in England and Wales was by then dominated by small shops. A system of many buyers and sellers, none of them dominant, was close to Adam Smith's understanding of a perfectly competitive market. Retailing was not generally seen as a problem to be controlled. Later, Central Place Theory (CPT) became influential. This powerful pan-European influence was comprehensively described by Potter (1982) writing at the height of its influence. Its inherent concept of the hierarchy implies maximally-efficient access to 'centres' which are presumed to offer the ideal mix of services to suit local demands. However, as noted elsewhere, (Whysall and Hallsworth, 2017) CPT blandly assumes that goods and services are locally supplied in line with local demand - rather like utilities. In the real world, highly competitive 
corporations jostle for power: hence the adoption of Institutional Theory as a theoretical framework for analysis in this study in order to inform on the activities of businesses. As a few powerful retail firms have all but obliterated the small independent shop, ignorance of corporate activities and agendas becomes an evermore-serious omission. Similarly, planning per se was not able to stop the later emergence of 'food deserts' in the UK (Wrigley, 2002) and North America (Paez et al., 2010; Wang and Qiu, 2016). Inevitably, too, land use control policies that restricted supply pushed up the value of the holdings of existing landowners.

Linking directly to this study's focus on physical manifestations of long-term change, strains were created in the 1960 s by attempts to take retailing out to the suburbs where the more car-mobile Britons were now living. Retailers wanted to move to locations, and larger formats, that town and city planners did not then deem suitable. In 1963, a US-style regional shopping 'mall' was proposed at Haydock Park near Liverpool. By then, many shops and shopping centres were owned by powerful institutional landlords who set long-term rental income targets (Jackson, 2006). This may be why many British town centres ${ }^{1}$ were "redeveloped" with large enclosed shopping centres (Pioneers, Arndale).

But what of other retail formats? Cumulatively, intrusiveness is not confined to megadevelopments such as West Quay. Developing larger out of centre 'shed' style food stores also brought retailers the potential to own land and thus to directly cash in on rising property values. Retailers and developers of, especially, retail 'sheds' came together to lobby for change under the umbrella group 'Accessible Retail'. Similar vested interests supported plans to liberalise Sunday trading laws. Eventually, these developments led to the concentration of retail power into ever-fewer hands - another consequence of the economic and regulatory changes that benefitted WalMart in the USA in the post-war period (Serpkenci and Tigert, 2010). As recently as 1982, Tesco only had $8.7 \%$ of the grocery sector's overall market share in the UK. This had increased to $27.8 \%$ by July 2017. A few hypermarkets were built but most chains (led by ASDA) preferred the smaller, superstore, format (Hallsworth, 1998). One reason

\footnotetext{
${ }^{1}$ Making publicly-funded investments in civic reconstruction following wartime bombings.
} 
for this was that planning permission could be acquired more quickly (Guy, 1980; Dawson, 1980; Davies, 1976).

\section{Gaming the system}

Retailers seeking to build intrusive new formats led to gaming the system. In other words, planning laws were rarely watertight. Businesses scan the Institutional environment and seek to work with or around them. If a developer thought that local officials would permit a new store but that it might be rejected nationally, then its size would be set just outside the threshold for local determination. In 1972 and 1976 thresholds in the UK were set at 50,000 sq. ft. and 100,000 sq. ft. respectively (DoE, 1972, 1976). That said, some local politicians and officials wished to permit such stores for the promise of 'new jobs and low prices'- notably in the North which was already falling behind economically. Indeed, if local government, the Local Authority (LA), owned the land, it could gain a financial windfall from selling it for a retail store. Similarly, alongside the privatisation of public services (Atkinson, 2003; Vallance et al., 2017) has come a reduction in the role, importance and financial power of the LAs - leaving them potentially vulnerable to any promise of a cash windfall. Knowing this, developers in England and Wales could offer additional benefits (under the Section 106 Agreements system, which is now replaced by the more formulaic Community Infrastructure Levy). Under Section 106, a store might pay for an otherwise-unaffordable amenity such as a swimming pool. City councils often faced difficult decisions, whereby a planning permission refusal could be met with a planning acceptance for the same development in a competing town or city: leaving an impactful store nearby, but no windfall revenues. Similar scenarios have played out in many countries. This leads neatly into a case study of how dominant French retailer Carrefour came to venture into England and Wales.

\section{Case study: Carrefour}

In a minority partnership with British wholesalers Linfood, Carrefour opened its first UK hypermarket at Caerphilly in South Wales on $13^{\text {th }}$ September 1972. Later 
developments included Chandlers Ford, Hampshire and Patchway, Bristol. The consensus is that the planning system disliked the visually-intrusive hypermarket format and only a handful of Carrefour stores were built (Guy, 2002). So were these few Carrefour stores later demolished? Hardly so. Any opportunistic, and thus profitable, intrusion into hitherto-forbidden locations was bound to be attractive. One attraction, as Guy (2002) pointed out, was that these early huge stores were permitted with valuable A1 retail consents. In due course, those stores were sold on and now function as ASDA Wal-Mart outlets. So, some controversial formats have turned out to be surprisingly permanent. Note again that the retail revolution in the USA was initiated by WalMart and driven by its use of Regional Distribution Centres. This model was copied in the UK and Regional Distribution Centres have become arguably more influential than the large stores that they serve.

\section{The Thatcher revolution and reactions}

The neo-liberalism that attended the Reagan Presidency in the USA arguably benefited WalMart. In Britain, the election of the neo-liberal Thatcher government in 1979 brought a similar watershed .Though her greatest impact was the liberalisation of banking and finance, Thatcher presaged a pro-big-business revolution. The fulltime, predominantly male, 'Fordist' wage supporting a family gave way to lowerpaid, less skilled work. Established retail firms responded to this transformed client base: middle/mass-market non-food retailers suffered: C\&A left Britain and others closed. Those retailers dependent upon the 'big middle' faced the greatest problems. Others who might have profited from the Thatcher liberalisations were slow to realise the new opportunities - unlike WalMart who rapidly exploited the neo-liberal postReagan economic climate. All in all, longstanding planning preoccupations over the potential impact of new developments on old were now downplayed (Norris, 1990). The trends were driven by a key 'agent' of change, Thatcher's pro-development Environment Secretary, Nicholas Ridley, who even offered private businesses the freedom to sue elected governments over an unfavourable planning decision. However, objectors still cannot appeal when permission is given to a proposal to which they object. So, Nicholas Ridley became a key agent of change simply by weakening planning powers. 
As regards the transformation of urban planning landscapes, the (neo)-liberalising 1980s are a particularly transformative period (Home, 1991). Canary Wharf was built in London with the financial support (including Docklands Light Railway) of the country's Prime Minister: Mrs Thatcher. However, there was an 8-year time-lag between her election and its opening (Church, 1990). Likewise, Battersea Power Station - now the general location of residential blocks - stood decommissioned since 1983. During the 1980s laissez-faire period, there were several attempts to build new mega-scale US-style shopping 'malls' in England: many at intersections of London's M25 orbital motorway ${ }^{2}$. However, with the recession that accompanied Thatcher's election, many such projects were abandoned or delayed. Also, so many 'malls' were proposed that it was obvious to all that, cumulatively, they would have an enormously damaging impact on existing property investments (Norris, 1990). So, in Institutional terms, there was a countervailing power: existing Institutional investors including landlords. They had real influence in the 1980s in slowing London's potential growth of malls. More widespread fears of competitive impact were also a huge incentive for town centre management (TCM) schemes (Stubbs et al., 2002). Nevertheless, the period from 1979 to 1996 was a golden age for retail planning permissions for peripheral stores (e.g. Larkham and Pompa, 1989). So, any retail responses to policy tightening (Wood et al., 2006; 2010) came only after a long period of largely unfettered suburbanisation. So, what happened/ is happening to superfluous High Street retail units following retail decentralisation? In 2018, after a decade of postsub-prime slow growth, struggling High Street retailers were reported to be begging their landlords for rent decreases. In many cases, charity shops had taken over vacant high street premises (Alexander et al., 2008; Wrigley and Dolega, 2011) and car boot sales boomed. The 'pound store' phenomenon ${ }^{3}$ began in the recession of the early 1990s whilst food banks only arrived in numbers after the sub-prime recession.

\footnotetext{
${ }^{2}$ Eventually, two (BlueWater Park and Lakeside) were built to the east of London but the former Dunstan power station at Gateshead - redeveloped with much public money - offered a lucrative windfall to local developer John Hall. Similar 'Malls' were built at other of the so-called Enterprise Zones.

${ }^{3}$ The North American equivalent - Dollar stores - began at the same time.
} 


\section{Sunday trading and $\mathbf{1 9 9 6}$}

Margaret Thatcher left office on $28^{\text {th }}$ November 1990 having lost only one parliamentary vote: the market-liberalising policy of Sunday opening for shops - a defeat repeated by a later Conservative government on $9^{\text {th }}$ March, 2016. This is a reminder that trading laws as well as retail planning can influence retail outcomes. Small, independently-owned shops cannot compete with 24 hour trading (Ozuduru et al., 2014) - now offered in Britain with only a brief respite on Sundays. The current situation was last influenced by Thatcher's Conservative successor, John Major, who eventually liberalised Sunday trading. Yet, by 1996, there were signs of a return to more one-nation values for retailing. This was driven by another key 'agent': Environment Secretary John Selwyn (now Lord) Gummer. His personal beliefs led him to believe that free-marketeering had gone too far. The result was the Planning Policy Guidance Note 6 (PPG6): Town Centres and Retail Developments, issued in 1996 (DETR, 1996; ODPM, 2005). The influential 1996 document came after evidence had emerged that the out-of-town exodus was indeed damaging and so, thereafter, the viability of town centres and the vitality of rural economies had to be taken into account. An earlier study by URBED (1994) concluded that only $3 \%$ of market towns in the UK considered themselves to be vibrant and as many as $15 \%$ were in decline. Note, too, the September, 1998, report for the Department of the Environment/DETR (SEC/SETRA, 2000; Wrigley et al., 2010), which indicated that superstores were negatively affecting market towns. By the mid-1990s Britain had permitted roughly 1,000 superstores (France had 1,000 hypermarkets by 1994) and they were taking over half of the grocery sales by value. This sat alongside a vast reduction in choice when measured by choice of retail store chains of which some 60 were taken over or closed down from 1945 onwards.

Gummer's PPG6 (1996) addressed concerns over the vulnerability of small town centres to damage from food superstores by imposing the so-called 'sequential approach' to store site selection (Hallsworth, 2010, 2014). Although PPG6 was ideologically a Conservative initiative, it continued in the early years of Tony Blair's 'New Labour' government, with subsequent initiatives such as the Urban White Paper of 2000 (Rae, 2013). Later revisions (e.g. Planning Policy Statement 6: Planning for Town Centres - also known as PPS6 - introduced in 2005) implied a more proactive 
approach by LAs - beyond the reactive approaches evident earlier. Yet still there emerged the 'Tesco Town' phenomenon where every store appeared to be a Tesco. This also demonstrates that Tesco was the retail chain most alert to future growth possibilities - even in times of recession. Some feared that more new stores might bring more space than was needed (or could be sustained by spending growth) and might out-compete a 'sequentially-preferable' central store causing it to close. Supporters of unfettered competition saw this as the workings of the free market in increasing choice and driving down prices.

Hence, as Guy (2006) explained:

“A [...] problem for retail developers arose ... (Caborn, 1999): they would have to demonstrate that there was a 'need' for the store(s). ....arguments that the new development would enhance efficiency, competitiveness, and innovation were insufficient grounds [...] (Adlard, 2001" (Guy, 2006; p758)

Caborn was promoting 'Town Centres First' and successive British governments have also claimed to hold to a Town Centres First policy but, depending on how one defines a Town Centre, the floorspace figures rarely support this claim. Measuring matters differently, Hart et al. (2013) claimed that Town Centres remained the preferred destination for shopping and yet indicated that only $32 \%$ of all retail trips were made to town centres. The study is notable because of its emphasis on Town Centres per se and its widespread backing (from a Research Council, leading retailers and pro-Town Centre groups). This is testimony to wider efforts from pro-community businesses to support centres through wider place management initiatives such as town centre management (TCM) and Business Improvement Districts (BIDs) (Jones et al., 2003), which are considered next.

\section{Protecting town centres and managing them actively}

As noted, mostly from the 1980s onwards, governments reacted against retail sprawl affecting most European towns and cities. Policy reactions (Guy 1998) focused on impacts on rivals from over-sized stores. Accordingly, TCM emerged 
in England in the 1980s as a "comprehensive response to competitive pressures [...] involving [the] development, management and promotion of both the public and private arenas within town centres, for the benefits of all concerned" (Wells, 1991; p. 24). TCM adopted a more strategic approach in the 1990s (Ashworth and Voogt, 1991) with innovative partnership-based activities (including BIDs) emerging in the UK (Whyatt, 2004; Cook, 2008) and mainland Europe (Forsberg et al., 1999; Coca-Stefaniak et al., 2009). Contrasting with the European Court of Justice (ECJ) ruling in 2011 which forced Catalonia to accept more large stores, community engagement and local identity drove informal town centre schemes led by small independent retailers in Italy (Codato, 2010), Spain (Crespi-Vallbona and Dimitrovski, 2017) and France (Cossardeaux, 1999). That such a movement arose is testimony to the shift in balance of power away from established centres.

TCM has evidently outgrown its retail-focused beginnings with a more holistic and longer-term vision of town centres incorporating strategic regeneration and sophisticated place branding (Rabiossi, 2015). Yet the decline in the small shop retail sector over the last two decades (Coca-Stefaniak et al., 2004) has been largely mirrored by underperforming high streets in much of England and Wales (BIS, 2011). This fall in vitality, attractiveness and resilience of town centres became the focus of Government-funded studies (BIS, 2011; Wrigley and Lambiri, 2015). Similarly, though the number of TCM schemes in the UK stands at an all-time high of over 600 , their actual contribution to the vitality and resilience of town centres remains under-researched.

\section{Enter the Treasury}

However appealing the concept of community, very different keywords (typically: productivity, efficiency and competitiveness) seem more appealing to British governments and to The Treasury in particular. Following Caborn, a tightening of the 'Sequential test' came with the 'Need Test': a simple pass/fail hurdle that could be understood by the dwindling band of retail-aware planners. Voices advising The Treasury, however, insisted that this was stifling competitiveness and there ensued a major return to retail liberalisation following the Barker Review of Planning in 
England \& Wales (2006). The Barker Review was conducted not by planners but by the Treasury and the then Office of the Deputy Prime Minister (ODPM). The stated objective of the Barker Review was to examine if planning rules in England \& Wales might be stifling "productivity" - a key Treasury concern. Many interested parties advised Barker on whether or not planning rules on retailing should be loosened. Unsurprisingly they split between those supportive of more out-of-town retail and those opposing it: the latter lost. The Need test was replaced by a more complex Impact Test. So 'tightening' of policy, after the neo-liberal years, only lasted until the demise of the Need Test in 2008. Thereafter, it became a business decision if one of the Big Four retailers entered a market where there might be insufficient local expenditure to support another store. Such a new store, having probably already generated windfall property profits, would inevitably take trade from incumbent rivals on and off the High Street: and so it proved.

\section{Retailing and competition policy}

One policy area of rising significance in recent years is that of business regulation in all its forms. Resale Price Maintenance (RPM) was a regulation from 1896 that was removed from Britain in January 1965. It had restrained volume discounters and its removal gave retailers power over manufacturers and spurred the move to out of town retailing. This reinforces the importance of non-planning regulations such as the 2011 European Court of Justice (ECJ) ruling (above). Also, Britain once had a Monopolies and Mergers Commission to monitor business mergers that might not be in the wider public (indeed, national) interest. In 1999 it became the Competition Commission (CC) - with a remit to disregard any national interest and drive 'competition'. Indeed, the idea of a national interest per se was removed by the Enterprise Act of $2002-$ modelled on EU legislation. The concern that some pro-monopolistic mergers might be harmful (largely denied by free-marketeers) has declined to the extent that the regulatory body is now the Competition and Markets authority.

However, the notion of competitiveness and the ongoing rise of an oligopoly of major retailers attracted the attention of the now-defunct CC twice in the 2000s. In 2000, (CC, 2000) action was prompted by a campaign in The Sunday Times newspaper: 
"Rip off Britain" (see also Wrigley, 1993). Director-General of Fair Trading Professor John Bridgeman required the $\mathrm{CC}$ to launch a Supermarkets Inquiry. That inquiry identified two non-overlapping markets: convenience and one-stop shopping. By 2003, Tesco and Sainsbury had moved into the convenience sector and the two markets notion collapsed. However, a largely-ineffectual Code of Practice for Supermarkets (GSCOP) was enacted.

Soon the EU-influenced 2002 Enterprise Act was enforced and changed the mindset of Competition Law - again in the direction that market-dominant mega-corporations formed from merger activity were not a problem. This sits in contrast to the longstanding counter viewpoint - voiced in the USA, for example, by the Open Markets Institute (2018) - that small businesses are important. This is echoed, too, in Germany (Wortmann, 2004) with its inherent support for the Mittelstand. Back in Britain, the CC managed the decline of Safeway by engineering its takeover (CC, 2003 ) by its smaller rival Morrisons. So, the domestic food retail system of 2000 became more concentrated within just three years. Importantly, changes in Competition Law facilitated ever-increasing market concentration. This leaves megafirms with the power to abuse weaker rivals and suppliers. In recent times up to $75 \%$ of UK grocery retail shelf space has been controlled by four big retailers (in 2017 this subsided to $69.3 \%$ ). Hundreds of suppliers have to gain access to millions of consumers via those shelves. Control therefore resembles an hourglass with dominant retailers controlling the shelves - the crucial "pinch point" in the middle (Sables, 2014).

2006 brought the 2006-8 Groceries Inquiry (CC, 2006-8) after the Association of Convenience Stores (ACS) lobbied for another investigation. Yet this included two issues that ACS did not raise: the holding of land banks by major retailers and the possible role of Land Use Planning as a factor 'distorting competition'. ${ }^{4}$ Furthermore, under the now-dominant Chicago School competition mindset, consumer welfare no longer needed to involve real consumers. All that mattered was to have structures in place that should in theory (if not in practice) be competitive. This prioritised Competition matters over Planning concerns and the CC even sought to superimpose

\footnotetext{
${ }^{4}$ Those who desire fair competition argue that planning valuably limits excessive free competition
} 
its own Competition Test to control store location (see Hughes et al., 2009). This stilldormant 'Test' would restrain any one of the Big Four from further building in a local area where it already held a dominant position. The rigid low-price-fixated Chicago School competition mindset (Davies, 2010) also places no value on the 'societal' factors so important to more community-focused interests. Davies has also suggested that such attitudes now also drive EU policymaking. Equally, the $\mathrm{CC}$ was unconcerned about how many small rivals might be destroyed as the Big Four came to dominate. Opposition to this was voiced by NEF (2005, p5) thus "The death of diversity undermines democracy, attacks our sense of place [...] hands power to an unaccountable corporate elite". The Chicago School mindset also underpinned the 2008 sub-prime financial meltdown from which Europe still suffers today.

\section{Retailing, power and the abuse of power}

As retailing evolves, power and power imbalances assume greater significance. Central Government and the retailers can exert power over the LAs (Pal et al., 2001; Burt and Sparks 2003; Pal and Medway, 2008). The dominant superstore retailers are now large, powerful landowners. At the height of retail property prices, Tesco amassed a property portfolio worth over $£ 30$ billion. Vast assets confer the power to buy information and use it to their advantage. Essentially, access to good data remains a problem that still endures (Wrigley and Lambiri, 2015). A further power available to the powerful is influence over political decision-making: Sparks (2008) used Freedom of Information rules to disclose that Wal-Mart had lobbied the then Prime Minister, Tony Blair, for a relaxation of planning rules. Sensibly, they would have preferred the UK to have an Institutional environment closer to the one in which they thrived domestically - and had the influence to request it. Reference was made (above) to Resale Price Maintenance (RPM) and, as outlined by Ryle (2013, pp. 52-56) the founder of TESCO, Jack Cohen, lobbied tirelessly for the repeal of RPM. This confirms that retailers are aware of, and seek to change, parts of the Institutional environment that do not suit their ambitions.

Others, naturally, oppose change: in 2002, the then Mayor of Barcelona, Joan Clos, wrote of its social cohesion around its Agora, or market. He wrote: "where [...] it is 
pleasant to stroll, to see and be seen, and to have ...commerce, services and recreation near home...tourists increasingly appreciate a shopping city where they can stroll..." (Barcelona, 2002; pp. 2-3). Transparently, this is the pedestrian environment of the typical Mediterranean culture, lifestyle and diet based on local, fresh produce. Equally, it is the antithesis of the transnational hypermarket which characterises the retail structure of Britain (Dawson, 2000). Yet the ECJ did not hesitate to overrule Catalan lifestyle and to promote the transnational hypermarket: enforcing more 'competition' and visual intrusiveness.

Yet how robust is the hypermarket-led British system in the face of economic change in the post-sub-prime era? In another study of the effects of regulation on local outcomes, Kim and Hallsworth (2015) described the troubles afflicting Tesco since July 2014. Indeed, it may be that Tesco mis-read ongoing changes - and in not just in the Korean market. Tesco, in 2013, made a £804m write-down in its value of British property holdings: undermining future prospects for superstores. Some 176 sites that would have been turned into superstores would no longer be developed. The USA, too - where Tesco closed its Fresh \& Easy venture - remains difficult to read. Meanwhile, post-sub-prime, British shoppers began flooding to the low prices offered by Aldi, Lidl and 'pound stores'. 5 The smaller stores of Aldi and Lidl do not conflict with Need, Sequential or similar retail planning restraints. They have modified their original 'hard discount' format to recreate the old High Street supermarket: sometimes boosting the High Street itself. This links to the 'Wheel of Retailing' model (Brown, 1988) which predicts undercutting of top heavy businesses by 'lean and mean' competitors (who in this case, being family-controlled, also avoid stock market pressures (Wortmann, 2004)). Tesco and Sainsbury in particular offer costly loyalty card benefits. Home delivery, too is something that Aldi and Lidl do not offer. However, with so much floor space out of town and still impacting much of the UK's town centres, High Street decline research continues to thrive (Findlay and Sparks 2013; Wrigley and Lambiri, 2015). Much of the food sales apparently lost to the internet is nevertheless served by the Big Four retailers (though Morrisons lags). Home delivery is not yet a financially-sustainable project and the Big Four retailers seek to devote parking spaces to the far cheaper 'click and collect' option. So, the

\footnotetext{
${ }^{5}$ For a consideration of the rise of foodbanks see Dobson and Papworth (2015)
} 
leading UK food retailers are wedded to a format - the superstore - that is expensive to build and now vulnerable to the predations of low-cost rivals run by ALDI and Lidl. So it would appear that the days of high-cost and visually-intrusive new retail formats may be over. Indeed, in a Brexit-dominated country it is not yet clear where finance, and the confidence to spend it building palaces of consumption, will be found.

\section{And so to the internet}

The most notable spatial manifestation of the Internet is the system of Regional Distribution Centres that serve their businesses. Unlike physical stores they seem to attract little planning opposition. Items such as computers and smartphones are now popular web-purchases whereas the Phones $4 U$ business - operating from High Street outlets - collapsed. Although a detailed exploration of internet shopping trends is beyond the remit of this study, it cannot be ignored and Amazon are now active in the grocery supply market. The internet, of course, utterly undermines the notion within CPT that goods and services are locally supplied in line with local demand. What we should beware, however, is the assertion that all the troubles of the High Street are caused by the Internet. As we have seen, the dominant food retailers fled out-of-town and are now being undercut by more mundane 'hard discount' formats. However, the vacancy levels on High Streets serve to drive agendas that do not see retail as the only important player. One trend, much as local 'pubs' are being converted to convenience stores, is that unprofitable surplus retail units are being redeveloped as profitable housing: a logical commercial decision. So, in places, the retail skyline is becoming a housing skyline. Even more recent proposals include plans to build residences above new, freestanding, superstores.

\section{Conclusions}

Over the course of 80 years, the nature, and locations, of retail outlets in England and Wales have both been dramatically transformed and so, too, has the physical townscape. Large food superstores, non-food retail 'sheds' and a limited number of even more visually intrusive US-style 'Malls' have come to be built. However, when 
considering this change through the lens of Institutional Theory, it becomes clear that many and diverse forces are at work. This was presaged by Evers (2002) who observed the uneven struggle between planning just one (of many) possible nationally-regulated policy instruments and neo-liberalism: the dominant economic ideology. Influenced by the latter, British society is far more socially and economically diverse and divided than when Land Use planning was in its heyday. Presently, increasingly powerful retailers interface with decreasingly powerful planners. Wider changes in economic outlook and the privileging of the market and individualism as a result of Thatcherism/ neo-liberalism link to the sub-prime banking crisis that has also affected the profits of retailers. Increasingly, though retail planning regulations are still about the use to which land is put, the influence of planning itself has waned. This study has noted how - and why - the willingness of governments to exert meaningful influence on development via planning rules has ebbed and flowed since 1947. To complicate matters further, attitudes and policies held by various government ministries are often contradictory (Guy, 2006); plus there has been a remarkable willingness by Competition Authorities to intervene in retail planning issues. This re-emphasises how important Institutional factors are. Worse, although strong statements may be made by central government, planning enforcement falls to Local Government which may have few incentives to uphold them. Indeed, The National Planning Policy Framework (DCLG, 2012) published on 27 March 2012 set out not just the Government's planning policies for England but also 'how these are expected to be applied'. This paper has focused on the practicalities of the latter aspect and the implications for town centre management in a land where regional devolution of real power remains rather scant. What is also clear is that the UK's dominant retailers may have miss-read the changing trading/ Institutional environment and are, to that extent, the architects of their present misfortunes.

\section{References}

ADLARD, H. (2001), “The 'need' for retail development”, Journal of Planning and Environmental Law, May, pp 522-534. 
ALEXANDER, A., CRYER, D. and WOOD, S. (2008), "Location planning in charity retailing", International Journal of Retail and Distribution Management, 36(7), pp. 536-550.

ASHWORTH, G.J. and VOOGDT, H. (1991), Selling the City: Marketing Approaches in Public Sector Urban Planning, Wiley: Chichester.

ATKINSON, R. (2003), "Domestication by cappuccino or a revenge on urban space? Control and empowerment in the management of public spaces", Urban Studies, 40(9), pp. 1829-1843.

BARCELONA (2002), Barcelona: Commercial Districts of Barcelona, Barcelona: City of Barcelona.

BARKER, K. (2006), The Barker Review of Planning in England \& Wales, London: HMSO.

BEAUMONT, C.E. (1994), How Superstore sprawl can harm Communities: and what citizens can do about it, Washington, DC: US National Trust for Historic Preservation.

BIANCI, C. (2008), "Retail internationalization from emerging markets: Case study evidence from Chile", International Marketing Review, 26, pp 221-243.

BIS (2011), Understanding high street performance, Department for Business, Innovation and Skills, London, available at https://www.gov.uk/government/uploads/system/uploads/attachment_data/file/31823/ 11-1402-understanding-high-street-performance.pdf (accessed 3 August 2015).

BROWN, S. (1988), "The wheel of the wheel of retailing", International Journal of Retailing, 3, pp 16-37.

BURT, S. and SPARKS, L. (2003), "Power and competition in the UK retail grocery market”, British Journal of Management, 14, pp. 237-254. 
CABORN, R. (1999), Parliamentary Answer, 11 February Hansard column 309 CB Hillier Parker, Cardiff University, 2004 Policy Evaluation of the Effectiveness of PPG6 Office of the Deputy Prime Minister, London.

CHURCH, A. (1990), "Transport and urban regeneration in London Docklands: A victim of success or a failure to plan?", Cities, 7(4), pp.289-303.

COCA-STEFANIAK, J.A., HALLSWORTH, A.G., PARKER, C., BAINBRIDGE, S. and YUSTE, R. (2004), "Decline in the British small shop independent retail sector: exploring European parallels", Journal of Retailing and Consumer Services, 12, pp. 357-371.

COCA-STEFANIAK, J.A., RINALDI, R., PARKER, C. and QUIN, S. (2009), "Evolution of town centre and place management models: a European perspective", Cities, 26, pp. 74-80.

CODATO, G. (2010), "Perspectives, trends and opportunities in city management in Italy: What new challenges lie ahead?", Journal of Town and City Management, 1(1), pp. 11-22.

COMPETITION COMMISSION (CC) (2000), Supermarkets: A report on the supply of groceries from multiple stores in the United Kingdom, London, The Stationery Office: Volume 1: Summary and Conclusions (Cm 4842).

COMPETITION COMMISSION (CC) (2003), Safeway plc... A report on the Merger in Contemplation, London: The Stationery Office.

COMPETITION COMMISSION (CC) (2006-2008), Groceries Market Investigation: Final report, London: The Stationery Office.

COOK, I.R. (2008), "Mobilising urban policies: The policy transfer of US Business Improvement Districts to England and Wales”, Urban Studies, 45(4), pp.773-795. 
COSSARDEAUX, J. (1999), "L'émergence du town management”, Les Echos, 20 September, p. 51.

CRESPI-VALLBONA, M. and DMITROVSKI, D. (2017), "Food markets from a local dimension-La Boqueria (Barcelona, Spain)” Cities, 70, pp.32-39.

DAVIES, R.L. (1976), Marketing geography, Corbridge: RPA.

DAVIES, W. (2010), "Economics and the 'nonsense' of law: the case of the Chicago antitrust revolution", Economy and Society, 39, pp. 64-83.

DAWSON, J.A. (1980), Retail Geography, London: Croom Helm.

DAWSON, J.A. (2000), "Retailing at century end: some challenges for management and research", The International Review of Retail, Distribution and Consumer Research, 10, pp. 119-148.

DoE: DEPARTMENT OF THE ENVIRONMENT (1972), Development Control Policy Note 13, London: The Stationery Office.

DoE: DEPARTMENT OF THE ENVIRONMENT (1976), Development Control Policy Note 13, London: The Stationery Office.

DETR (1996), Planning Policy Guidance: Town Centres and Retail Developments (Revised PPG6, June 1996),

http://regulations.completepicture.co.uk/pdf/Planning/Planning\%20Policy\%20Guidan ce\%206-\%20Town\%20centres\%20and\%20retail\%20development\%20.pdf (accessed 3 August 2015).

\section{DCLG DEPARTMENT FOR COMMUNITIES AND LOCAL GOVERNMENT} (2012), The National Planning Policy Framework, London: The Stationery Office. 
ETRA (ENVIRONMENT, TRANSPORT AND REGIONAL AFFAIRS

COMMITTEE) (2000), Environmental Impact of Supermarket Competition, Second

Report,www.publications.parliament.uk/pa/cm199900/cmselect/cmenvtra/120/12006.t

m (accessed 3 August, 2015), Environment, Transport and Regional Affairs

Committee.

EVERS, D. (2002), "The rise (and fall?) of national retail planning", Tidjschrift voor Economische en Sociale Geografie, 93(1), pp. 109-113.

FERNANDES, J.R. and CHAMUSCA, P. (2014), “Urban policies, planning and retail resilience", Cities, 36, pp. 170-177.

FINDLAY, A. and SPARKS, L. (2013), "Reviewing high streets and town centres", Town and Country Planning, 82(11)

FORSBERG, H., MEDWAY, D. and WARNABY, G. (1999), “Town centre management by co-operation: evidence from Sweden", Cities, 16(5), pp. 315-322.

GUY, C.M. (1980), Retail location and retail planning in Britain, Farnborough: GOWER.

GUY, C.M. (1998), "Controlling new retail spaces: the impress of planning policies in Western Europe", Urban Studies, 35, pp 953-979.

GUY, C.M. (2002), "Is retail planning policy effective? The case of very large store development in the UK", Planning Theory and Practice, 3, pp. 319-330.

GUY, C.M. (2006), "Retail productivity and land use planning: negotiating `joinedup' retail planning policy", Environment and Planning C: Government and Policy, 24 pp. $755-770$.

HALLSWORTH, A.G. (1997), "Rethinking retail theory: Circuits of power as an integrative paradigm", Geographical Analysis, 29, pp. 329-338. 
HALLSWORTH, A.G. (1998), "Superstore impact: not just space but time”, Town and Country Planning, 67, pp. 352-353.

HALLSWORTH, A.G. (2010), "Small shop decline: shadow boxing in the dark", Environment and Planning A, 42, pp. 1258-1263.

HALLSWORTH, A.G. (2014), "Planning for retail change", Town and Country Planning, 83 (6/7), pp. 268-271.

HALLSWORTH, A.G. and TAYLOR, M. (1996), "Buying power: interpreting retail change in a circuits-of power framework", Environment and Planning A, 28, pp. 21252137.

HANDELMAN, J.M. and ARNOLD, S.J. (1999), "The role of marketing actions with a social dimension: Appeals to the institutional environment", Journal of Marketing, 63(3), pp. 33-48.

HART, C., STACHOW, G. and CADOGAN, J.W. (2013), “Conceptualising town centre image and the customer experience", Journal of Marketing Management, 29(15-16), pp. 1753-1781.

HOLLAND, B. (2015), "Typologies of national urban policy: A theoretical analysis", Cities, 48, pp.125-129.

HOME, R.K. (1991), "Deregulating UK planning control in the 1980s", Cities, 8(4), pp. 292-300.

HUANG, Y. and STERNQUIST, B. (2007), “Retailers' foreign market entry decisions: An institutional perspective”, International Business Review, 16(5), pp. 613-29.

HUGHES, R., CLARKE, G. and HALLSWORTH, A.G. (2009), “Testing the effectiveness of the proposed UK 'Competition test'”, The Service Industries Journal, 29, pp. 569-590. 
JACKSON, C. (2006), "Retail planning and institutional property investment", Regional Studies, 40(5), pp. 555-561.

JONES, P., HILLIER, D. and COMFORT, D. (2003), "Business improvement districts in town and city centres in the UK", Management Research News, 26, pp. 5059.

KIM, W. and HALLSWORTH, A.G. (2015), "Tesco in Korea: Regulation and retail change", Tidjschrift voor Economische en Sociale Geografie, DOI:10.1111/tesg.12145

LARKHAM, P.J. and POMPA, N.D. (1989), "Planning problems of large retail centres: the West Midlands County, 1987”, Cities, 6(4), pp. 309-316.

LOWE, M.S. (2000), “Britain's regional shopping centres: new urban forms?”, Urban Studies, 37(2), pp. 261-274.

NEW ECONOMICS FOUNDATION (NEF) (2005), Clone Town Britain, London: New Economics Foundation.

NORRIS, S. (1990), “The return of impact assessment”, Papers of the Regional Science Association, 69, pp. 101-119.

OFFICE OF THE DEPUTY PRIME MINISTER (ODPM) (2005), Planning Policy Statement 6: Planning for Town Centres, London: Office of the Deputy Prime Minister.

OPEN MARKETS INSTITUTE (2018) The Corner: newsletter, https://openmarketsinstitute.org/ (accessed $11^{\text {th }}$ January, 2018)

OZUDURU, B.H., VAROL, C. and ERCOSKUN, O.Y. (2014), "Do shopping centers abate the resilience of shopping streets? The co-existence of both shopping venues in Ankara, Turkey", Cities, 36, pp. 145-157. 
PAEZ, A., GERTES MERCADO, R., FRABER, S., MORENCY, C. and ROORDA, M. (2010), "Relative accessibility deprivation indicators for urban settings: definitions and application to food deserts in Montreal”, Urban Studies, 47(7), pp. 1415-1438.

PAL, J., BENNISON, D., CLARKE, I. and BYROM, J. (2001), "Power, policy, networks and planning: the involvement of the major grocery retailers in the formulation of Planning Policy Guidance Note 6 since 1988”, International Review of Retail, Distribution and Consumer Research, 11, pp. 225-246.

PAL, J. and MEDWAY, D. (2008), "Working the system", Environment and Planning A, 40, pp. 761-765.

POTTER, R (1982), The Urban Retailing System, London: Gower.

RABBIOSI, C. (2015), "Renewing a historical legacy: Tourism, leisure shopping and urban branding in Paris", Cities, 42, pp. 195-203.

RAE, A. (2013), "English urban policy and the return to the city: A decade of growth, 2001-2011”, Cities, 32, pp. 94-101.

RAO, F. and SUMMERS, R.J. (2016), "Planning for retail resilience: Comparing Edmonton and Portland", Cities, 58, pp.97-106.

REEVES, C. (2015), Retail appeals bulletin, Cardiff: Reeves Retail Planning Consultancy Ltd.

RYLE, S. (2013), The Making of Tesco, London: Bantam books.

SABLES, D. (2014), "How retailers extract money from suppliers", The Grocer, $4^{\text {th }}$ October, pp. 15-16.

SCHILLER, R.L. (1986) "Retail decentralisation: the coming of the third wave", The Planner, 72, pp. 13-15. 
Select Committee on Environment, Transport and Regional Affairs (SETRA) (2000), Second Report: The Environmental Impact of Supermarket Competition, House of Commons Papers Session 1999-2000, London: The Stationery Office.

SERPKENCI, R. and TIGERT, D. (2010), “Antecedents and consequences of structural change in North American retailing 1990-2010", International Review of Retail, Distribution and Consumer Research, 20, pp. 29-68.

SPARKS, L. (2008), “Commentary: when Tony met Bobby”, Environment and Planning A, 40, pp. 2793-2799.

STUBBS, B., WARNABY, G. and MEDWAY, D. (2002), "Marketing at the public/private sector interface; town centre management schemes in the south of England", Cities, 19(5), pp. 317-326.

URBED (1994), Vital and viable town centres: Meeting the challenge, London: URBED.

VALLANCE, S., DUPUIS, A., THORNS, D. and EDWARDS, S. (2017), “Temporary use and the onto-politics of 'public'space”, Cities, 70, pp.83-90.

WANG, H. and QIU, F. (2016), “Fresh food access revisited”, Cities, 51, pp. 64-73.

WELLS, I. (1991), “Town centre management: a future for the high street", Geographical Papers, No. 109, Reading: University of Reading, p. 24.

WHYATT, G. (2004), “Town Centre Management: how theory informs a strategic approach", International Journal of Retail and Distribution Management, 32, pp. 346353.

WHYSALL, P. and HALLSWORTH, A. (2017), “40 years of retailing and marketing geography”, Paper. EARCD conference, Dublin July. 
WOOD, S., LOWE, M. and WRIGLEY, N. (2006), "Life after PPG6 recent retailer responses to planning regulation tightening”, International Review of Retail Distribution and Consumer Research, 16, pp. 23-41.

WOOD, S., LOWE, M. and WRIGLEY, N. (2010), "Conceptualising innovative customer-facing responses to planning regulation: the UK food retailers", The Service Industries Journal, 30, pp. 1967-1990.

WORTMAN, M. (2004), “Aldi and the German model”, Competition and Change, 8, pp. $425-441$.

WRIGLEY, N. (1993), “Abuses of market power?”, Environment and Planning A, 25, pp. 1545-1547.

WRIGLEY, N. (2002), “'Food deserts' in British cities: Policy context and research priorities", Urban Studies, 39(11), pp. 2029-2040.

WRIGLEY, N. and DOLEGA, L. (2011), "Resilience, fragility, and adaptation: new evidence on the performance of UK high streets during global economic crisis and its policy implications”, Environment and Planning A, 43(10), pp. 2337-2363.

WRIGLEY, N., LAMBIRI, D. and CUDWORTH, K. (2010), Revisiting the impact of large food stores on market towns and district centres, Southampton: University of Southampton.

WRIGLEY, N. and LAMBIRI, D. (2015), British high streets: from crisis to recovery? A comprehensive review of the evidence, Southampton: University of Southampton.

ZUKIN, S. (1993), Landscapes of Power, Berkeley: University of California Press. 